\title{
Talking Stick Learning Model, How Significant Is the Impact on the PGSD Students' Speaking Skills?
}

\author{
Loviniantika Cahyaning Suseno ${ }^{\mathrm{a}, 1, *}$, Haryanto ${ }^{\mathrm{b}, 2}$, Siti Anafiah ${ }^{\mathrm{c}, 3}$ \\ ${ }^{a, b}$ Pendidikan Dasar, Universitas Negeri Yogyakarta Jl. Colombo No.1, Sleman, Yogyakarta, 55281 Indonesia \\ ${ }^{c}$ Fakultas Keguruan dan Ilmu Pendidikan, Universitas Sarjanawiyata Tamansiswa Jl. Kusumanegara No.157, Yogyakarta, 55165 \\ Indonesia \\ Iloviniantikacs@gmail.com*; 2 haryanto_tp@uny.ac.id; 3 anafiahs@yahoo.com \\ * corresponding author
}

\begin{abstract}
ARTICLE INFO ABSTRACT
Article history

Received July 12, 2020

Revised Dec 17, 2020

Accepted Dec, 20, 2020

Keywords

Cooperative Learning Model

Talking Stick Learning Model

Speaking Skills

PGSD students

This study aims to identify differences in the PGSD students' speaking skills with and without talking stick learning model. This study uses a quantitative approach with a quasiexperimental design. The population was all students in the 4th semester with a total of 324 students. It involved 78 sample students selected using purposive sampling. Data were collected using speaking tests, observations, and interviews. The collected data were then analyzed using the Mann Whitney test. The result showed the Sig value of 0.000 which is lower than 0.05 and the average improvement in speaking skills of the experimental group is higher than the control groups. In conclusion, there are significant differences between students who received the talking stick learning model and those who did not.

Penelitian ini bertujuan menguji perbedaan keterampilan berbicara mahasiswa PGSD yang diberi model pembelajaran talking stick dan tidak. Penelitian ini menggunakan pendekatan kuantitatif jenis eksperimen semu. Populasi dalam penelitian ini adalah seluruh mahasiswa semester 4 sejumlah 324 mahasiswa dan sampel sejumlah 78 mahasiswa. Teknik pengambilan sampel penelitian yakni dengan purposive sampling. Data dikumpulkan menggunakan tes keterampilan berbicara, observasi, serta wawancara. Analisis data uji hipotesis penelitian ini menggunakan uji Mann Whitney. Hasil dari penelitian ini menunjukkan bahwa nilai Sig sebesar 0,000 lebih rendah dari 0,05 dan rata-rata perubahan keterampilan berbicara pada kelompok eksperimen jauh lebih tinggi daripada kelompok kontrol sehingga dapat disimpulkan bahwa terdapat perbedaan yang signifikan antara mahasiswa yang diberi model pembelajaran talking stick dan tidak.
\end{abstract}

This is an open access article under the $\mathrm{CC}-\mathrm{BY}$ license.

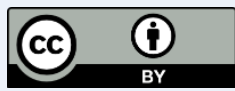

\section{Introduction}

All levels of education, from basic to tertiary level, use language as the primary means of communication. Therefore, educators and prospective educators have to be able to communicate with students using correct and appropriate Indonesian language in the teaching and learning process (Tarigan, 2015). Educators must master all language skills, including speaking. (Abbas, 2006) states that speaking is a way to convey messages from ideas, opinions, and intentions using spoken languages to make others easily understand the message conveyed.

The quality of the delivery of information from the teacher to the students becomes a priority in learning. Therefore, as a prospective teacher, each is required to have good speaking skills. As a part of language skills, speaking skills are relatively com- plex. This skill does not only deal with pronunciation, speech, and intonation but also another linguistic aspect including accuracy of pronunciation, appropriate diction, and appropriate target audience, as well as non-linguistic aspects such attitudes, expressions, fluency, loudness, and topic mastery, which have to be mastered to speak fluently (Akhadiah, 1991).

(Tarigan, 1991) states that speaking skills are a type of mechanical skill. It requires a sufficient training process to master this skill. Further, (Douglas \& Frazier, 2001) explains that speaking skills have a close relationship with a variety of other micro-skills and are categorized as complex skills. Ross and Roe (Rofi'uddin, \& Zuhdi, 1998) reveal that some activities can train students to practice speaking skills such as presenting information, participating in discus- 
sions, and presenting entertainment. Moreover, (Abbas, 2006) proposes several forms of learning that can improve speaking skills, namely reporting observations, conversations, describing, and exploring questions after exploratory activities, telling stories, interviews, speeches, and discussion.

A speaking test is an effective way to measure the level of students' speaking skills. Akhadiyah (Rofi'uddin, A \& Zuhdi, 1998) states that the speaking test can effectively measure a person's ability to communicate verbally. In this test, students can speak so that they can focus on speaking practices.

In terms of speaking practices, some students of prospective teachers at UST still have poor speaking skills. It was evident in the discussion session in which most students were less active in communicating their opinions and ideas, especially during discussing materials with a high level of difficulty. Factors affecting the less optimum of students' speaking skills cover (1) less optimum multidirectional discussion, less attention to linguistic and non-linguistic aspects in speaking, (2) students with good speaking skills, both in linguistic and nonlinguistic aspects, tends to dominate the discussions in the lecture, while those with poor speaking both in linguistic and non-non-linguistic aspect skill tend to be passive. The cause of this issue is the limited use of learning activities that can facilitate the student to develop their speaking skills.

Based on the field condition above, the researcher assumes the need for cooperative learning models. Cooperative learning is a term for a set of learning strategies that emphasize cooperation and interactions among students (Slavin, 2008). In addition to Slavin's opinion, (Jolliffe, 2007) states that cooperative learning emphasizes cooperation that is mutually supportive and beneficial among students to be able to develop the abilities of each individual as well as members of other groups equally.

Cooperative learning has eight aspects, according to (Jacobs \& Kimura, 2013), namely positive dependence, individual skills, equal opportunities to participate, frequent interaction in groups, heterogeneous groups, learning cooperation skills, and cooperation as the main values. (Jacobs \& Renandya, 2019) state that cooperative learning relates to student-centered learning. The measurement of the success of cooperative learning consists of four achievement indexes. They are consistent mastery of the material, the quality of the learning methods, the learning process, and learning transference (McConnel, 2014).

The talking stick learning model is one of the cooperative learning models. This learning model uses a talking stick in the learning process. After studying the material, the teacher proposes questions to the student who receives the stick (Kagan, 2009). Meanwhile, (Supridjono, 2009) explains that the purpose of the talking stick learning model is to awaken students' courage to express their opinions.

Furthermore, (Istarani, 2012) reveals that students' courage to express opinions can be improved through the use of a talking stick learning model. (Huda, 2015) states that the talking stick learning model is beneficial to make the students accustomed to speaking and be ready to respond to any situations.

The cooperative learning model has some advantages, such as able to find ideas and inspiration in learning and make students accustomed to using social and thinking skills (Isjoni \& Ismail, 2008). The talking stick learning model is a learning model that combines learning with games. It requires students to understand the material first. Then, they receive questions from the teacher and are required to give responses. Therefore, it provides chances for them to interact, to discuss, to be active in learning, to understand materials quickly, and to speak to respond to the questions.

Moreover, the results of the previous research conducted by (A. S. P. Sari \& Sembiring, 2019; Sartipa, 2017) showed that the use of the talking stick learning model can improve students' language skills. It indicated positive response of students in learning English using the talking stick learning model. All subjects believed that the use of the talking stick learning model managed to improve their English language skills.

Qualitative data analysis showed that the teaching and learning atmosphere becomes livelier and more enjoyable after the teacher applied the talking stick learning in the speaking class. Further, the students became more active and enthusiastic in speaking English. Another research (Hasyim, 2018) concludes that the establishment of the Students Achievement Division and Talking Stick on IHK, inflation, fiscal and monetary policy subjects in class XI of SMAN 2 Batu run well, as evidenced by the improvement in cycle 1 and cycle 1 from good to excellent categories. Besides, research conducted by (D. M. Sari, 2017) revealed that the implementation of the talking stick learning model showed differences in student characteristics in answer mathematical questions.

This research aims to identify the impact of the use of the talking stick learning model on the PGSD students' speaking skills at UST. It used a different learning model to identify the significant differences, namely the talking stick model and conventional model. 


\section{Method}

\section{A. Research Design}

This study uses a quantitative approach with a quasi-experimental research design.

\section{B. Research Setting}

This research was conducted in the Department of Science Education in Universitas Sarjanawiyata Tamansiswa. The subject of the research was students PGSD students in the 4th semester taking Child Literary subject at Universitas Sarjanawiyata Tamansiswa. The research was conducted in February May 2020.

\section{Research Population}

The population in this study was all PGSD students in the $4^{\text {th }}$ semester in UST, with a total of 324 students. This research used a purposive sampling technique. The determination of the experimental and control group used a draw in which class I was the control group, and class $\mathrm{F}$ was the experimental group.

\section{Data Collection}

The research used observation sheets to measure the feasibility of the talking stick learning model and the conventional learning model. The observation sheet was in the form of a checklist with yes and no responses. The instrument used to measure speaking skills was the speaking test sheet. This speaking skills test is to test the students' ability to speak, communicating the answers to questions they get in turn.

Table 1. Classification of Achievement Scores in Speaking

\begin{tabular}{ccc}
\hline No. & Category & Range \\
\hline 1. & Excellent & $8.0-10.00$ \\
2. & Good & $6.6-7.9$ \\
3. & Sufficient & $5.6-6.5$ \\
4. & Poor & $4.0-5.5$ \\
5. & Fail & $3.0-3.9$ \\
\hline \multicolumn{2}{l}{ a. Source: Suharsimi Arikunto, 2005}
\end{tabular}

\section{E. Data Analysis Technique}

This research was conducted in three stages. First, the data description stage requires pre-test and posttest data distribution summary in the form of the descriptive statistical results of the experimental and control groups. In the second stage, the prerequisite test stage used the equality test, normality test, and homogeneity test. The third stage is the hypothesis testing stage that used the Mann Whitney test as this research aims to compare the averages of the pre-test and post-test to find out the differences in speaking skills between the two groups.

\section{Results and Discussion}

The first step taken of this research was measuring a pre-test of 39 students from the experimental group, and the result showed that the mean value of students' speaking skills was 6.3. This value is considered enough as it is within the intervals of 5.6 6.5. Meanwhile, the mean value of the pre-test of the control group reached 6.5. It is also considered in a enough category. The highest value was in the gesture and speech politeness aspect with $10.78 \%$ for class $4 \mathrm{~F}$. Meanwhile, and the lowest value was in the loudness aspect, with $8.89 \%$ in class $4 \mathrm{I}$. The detailed result can be seen in Fig. 1. However, based on each aspect of speaking skills, the percentage of the pre-test result is presented in Table 2 .

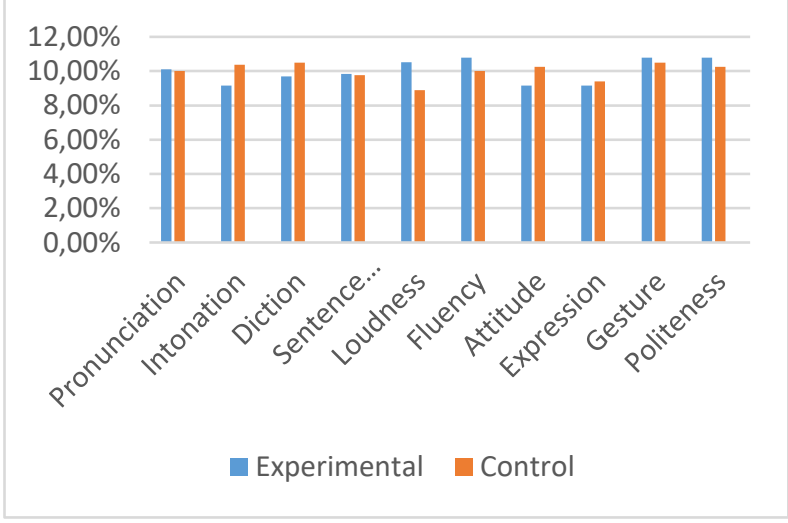

Fig. 1.The detailed result

Table 2. Percentage of Pre-test Result of Speaking Skills

\begin{tabular}{|c|c|c|c|}
\hline No. & Aspects & $\begin{array}{c}\text { Experimental } \\
\text { group }\end{array}$ & $\begin{array}{c}\text { Control } \\
\text { group }\end{array}$ \\
\hline \multirow[t]{5}{*}{1.} & Linguistic & & \\
\hline & Pronunciation & $10.10 \%$ & $10.01 \%$ \\
\hline & Intonation & $9.16 \%$ & $10.38 \%$ \\
\hline & Diction & $9.70 \%$ & $10.50 \%$ \\
\hline & $\begin{array}{l}\text { Sentence } \\
\text { structure }\end{array}$ & $9.83 \%$ & $9.76 \%$ \\
\hline \multirow[t]{7}{*}{2.} & Non-linguistic & & \\
\hline & Loudness & $10.51 \%$ & $8.89 \%$ \\
\hline & Fluency & $10.78 \%$ & $10.01 \%$ \\
\hline & Attitude & $9.16 \%$ & $10.25 \%$ \\
\hline & Expression & $9.16 \%$ & $9.39 \%$ \\
\hline & Gesture & $10.78 \%$ & $10.50 \%$ \\
\hline & Politeness & $10.78 \%$ & $10.25 \%$ \\
\hline
\end{tabular}

Measurement of the post-test of speaking skills in the control group was conducted on 39 students, and the result showed a mean score of 6.84 that is considered in the good category as within the interval of 6.6 - 7.9. Meanwhile, the post-test in the experimental group showed a mean score of 8 . This score is considered excellent as within the intervals of 8.010.00. The detailed result of the post-test can be seen in the following table. 
Table 3. Percentage of (\%) Post-test Result of Speaking Skills

\begin{tabular}{cccc}
\hline No. & Aspects & $\begin{array}{c}\text { Experimental } \\
\text { group }\end{array}$ & $\begin{array}{c}\text { Control } \\
\text { group }\end{array}$ \\
\hline 1. & Linguistic & & \\
& Pronunciation & $9.97 \%$ & $9.83 \%$ \\
Intonation & $9.97 \%$ & $9.83 \%$ \\
Diction & $10.08 \%$ & $10.33 \%$ \\
& Sentence & $9.77 \%$ & $9.71 \%$ \\
2. & structure & & \\
& Non-linguistic & & \\
Loudness & $10.18 \%$ & $9.33 \%$ \\
Fluency & $10.39 \%$ & $10.08 \%$ \\
& Attitude & $9.97 \%$ & $10.08 \%$ \\
& Expression & $9.67 \%$ & $9.21 \%$ \\
& Gesture & $9.87 \%$ & $10.21 \%$ \\
& Politeness & $10.08 \%$ & $11.33 \%$ \\
\hline
\end{tabular}

Based on Table 3, the highest percentage of speaking skills aspects is the fluency aspect with $10.39 \%$ in the experimental group, and the lowest is in the expression aspect with $9.21 \%$ in the control group. The researcher also provides the data in the form of a chart, and it can be seen in Fig 2 .

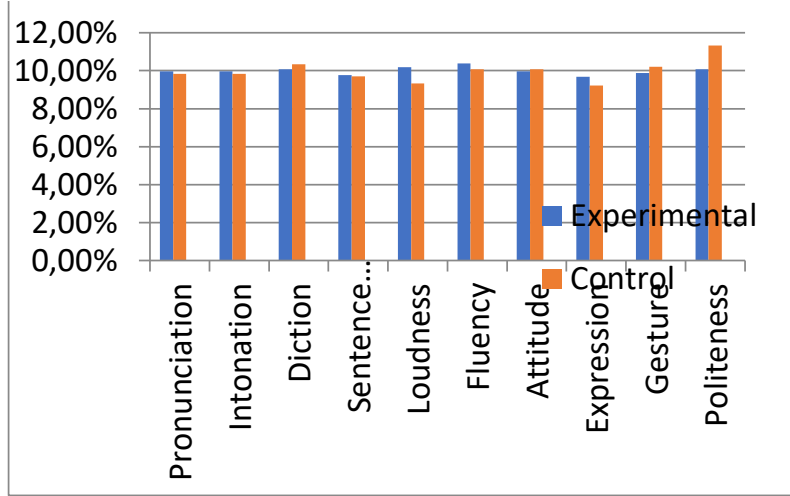

Fig. 2. The researcher also provides the data

Observations on each learning activity used the observation sheet in both the control and experimental groups. Based on the result of observations, in general, the learning conditions in the control and experimental groups are in accordance with the learning plan in that semester, and at the first, second, and third meetings, the learning plan has been implemented $100 \%$.

Table 4. Learning Implementation in the Experimental and Control Groups

\begin{tabular}{ccc}
\hline No. & Groups & Implementation \\
\hline 1 & Experimental & $100 \%$ \\
2 & Control & $100 \%$ \\
\hline
\end{tabular}

\section{A. Results of Data Analysis}

1) Data Normality Test

The result of the normality test using the Kolmogorov-Smirnov showed that the Asymp. Sig value was 0.006 for the pre-test and 0.003 for the post-test in the experimental group. Meanwhile, for the control, it was 0.015 for the pre-test and 0.011 for the post-test. It means the value is smaller than the alpha value of $5 \%(0.05)$. It indicates that the pre-test and post-test data of students' speaking skills do not have a normal distribution.

2) Homogeneity Test

The result of the homogeneity test using the Levene test showed a significant difference value of 0.698 which is higher than 0.05 . It indicates that the data were homogeneous.

\section{3) Hypothesis Test}

a) Mann Whitney U Test of Pre-test in Both Experimental and Control Groups

Based on the result of the Mann Whitney U test, the sig value of $0.169>0.05$ indicates that there were no significant differences in the results of the pre-test of the control and experimental groups. Students in both control and experimental groups had a similar initial level of speaking ability of 36.01 for the experimental and 42.99 for the control group.

b) Mann Whitney U Test for Pre-Post Test in the Experimental Group

The result of the Mann Whitney U test in the experimental group showed a significance value of $0,000<0.05$. It indicates that there is a significant difference between the pre-test and the post-test result in the experimental group. The average pre-test of the experimental group increased significantly from 21.53 to 57.47 in the post-test.

c) Mann Whitney U Test for Pre-Post Test in the Control Group

The result of the analysis using the Mann Whitney $U$ test showed a significance value of $0.001<$ 0.05 . It indicates that there were significant differences between the pre-test and post-test in the control group, in which it increased from 31.18 to 47.82 .

d) Mann Whitney U Test for Differences in the Speaking Skills between Control and Experimental Groups can be seen in Table 5.

Table 5. Mann Whitney U Test for Differences in the Speaking Skills between Control and Experimental Groups

\begin{tabular}{ccccc}
\hline Class & N & $\begin{array}{c}\text { Mean } \\
\text { Rank }\end{array}$ & $\begin{array}{c}\text { Sum of } \\
\text { Ranks }\end{array}$ \\
\hline $\begin{array}{c}\text { Speaking } \\
\text { skills }\end{array}$ & $\begin{array}{c}\text { Post-test of } \\
\text { experimental } \\
\text { group } \\
\begin{array}{c}\text { Pos- test of } \\
\text { control group } \\
\text { Total }\end{array}\end{array}$ & 39 & 54.59 & 2129.00 \\
& \multicolumn{3}{c}{ Statistics Test } \\
\hline \multicolumn{3}{c}{$\begin{array}{c}\text { Speaking } \\
\text { skills }\end{array}$} \\
\hline
\end{tabular}




\begin{tabular}{cccc}
\hline Class & N & $\begin{array}{c}\text { Mean } \\
\text { Rank }\end{array}$ & $\begin{array}{c}\text { Sum of } \\
\text { Ranks }\end{array}$ \\
\hline Mann- & 172.000 & & \\
Whitney U & & & \\
test & & & \\
Wilcoxon W & 952.000 & & \\
Z & -5.931 & & \\
Asymp. Sig. & .000 & \\
(2-tailed) & & \\
\hline
\end{tabular}

Based on the result of the analysis, a Significant value of $0,000<0.05$ indicates that $\mathrm{Ha}$ is accepted, and Ho is rejected. It can be concluded that the differences in speaking skills between the experimental and control groups were significant.

The result of the analysis also showed that the speaking skills in the control group had an average of 24.41 while in the experimental group, it was 54.59. It means that the difference in the speaking skills of the experimental group is higher than the control group. The result of the hypostasis test using SPSS 23.0 for Windows revealed that that the talking stick learning model has a significant impact on PGSD students' speaking skills in UST Yogyakarta.

This research analysed the impacts of a learning model. It discusses how the roles of the learning model, how it affects the students' speaking skills, and the challenges in using the model. The subject of this study was all students of $4 \mathrm{~F}$ and $4 \mathrm{I}$ classes of PGSD UST. The data were analysed using the Mann Whitney U test, and it revealed that the initial abilities of the control class and the experimental class have do not significantly differ.

After getting the results of the students' initial abilities, the researcher carried out the treatment to the experimental group, namely $4 \mathrm{~F}$ class using the talking stick learning model for children literature courses. Meanwhile, the control group, namely class 4I, kept using a conventional learning model through presentations, lectures, and assignments. The speaking skills, both in control and experimental groups, increased. First, in the experimental group, it improved from 21.53 (pre-test) to 57.47 (post-test). In other words, the increase is equal to 35.94 . Second, in the control group, it increased from 31.18 to 47.82 . It means that it increases 16.64 .

Moreover, the result of the Mann Whitney U test for the pre-post test showed a Sig value of 0.000 for the experimental group and 0.001 for the control group. It means the Sig value is smaller than 0.05 , so that both groups have significant differences based on the result of the pre-test and post-test. The students' initial speaking ability based on the pre-test showed an average of 6.3 for the experimental group and 6.5 for the control group (enough category). In the post-test, the value increased to 8 for the experi- mental group (excellent category) and to 6.84 (good category). The detail can be seen in Fig 3 .

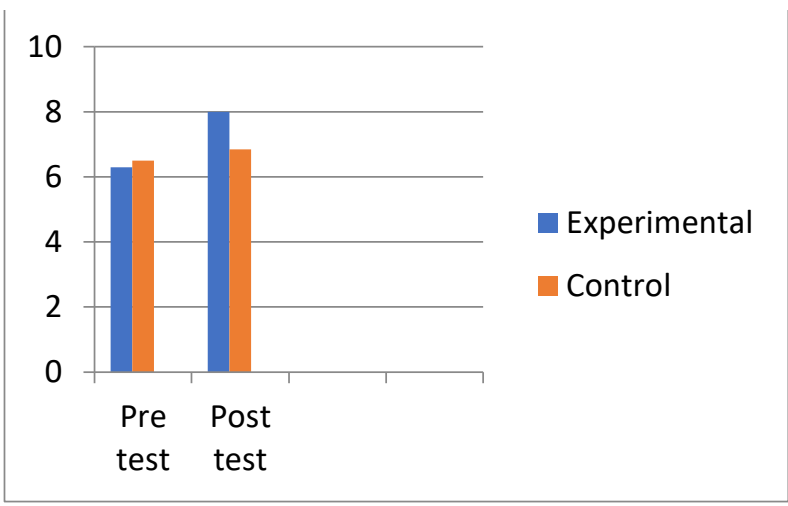

Fig. 3. The students' initial speaking ability

Based on the result of the analysis, the experimental group has a higher improvement in speaking skills compared to the control group. This is in line with the result of the previous research (A. S. P. Sari \& Sembiring, 2019) in which the use of the talking stick learning model can improve students' English language skills. The use of this model indicates very positive responses from students. All subjects agreed that the talking stick learning model effectively improved their English language skills. The qualitative data analysis shows that the atmosphere of teaching and learning becomes more lively and pleasant after implementing the talking stick learning model in the speaking class, and it resulted in higher student's participation and enthusiasm in speaking English.

Students' courage in expressing opinions can be improved through the implementation of the talking stick learning model in which when the lecturer explains a material, then students are given time to read and write what they know. After that, they give a stick to a student, and he/she must pass on the stick to others while singing a song together. The lecture proposes questions to the one who holds the stick when the song stops, and he/she is required to answer or respond to it. In line with (Sartipa, 2017), the talking stick learning model is a technique in which students are free to talk, express ideas and opinions, and answer questions. By using this model, students become more willing to speak using their own words without fear of mistakes. Therefore, this model can improve students' speaking skill as it triggers and provides opportunities for them to speak and express their opinions.

The benefit of implementing the talking stick learning model is to make students more willing to express their opinions and ideas in order to improve their speaking skills. (Huda, 2015) revealed the advantages of implementing the talking stick learning model, including testing how ready students are in answering questions, practicing reading skills and 
understanding materials, and encouraging students to always be ready in learning. It is in accordance with (Ananda, 2017) who stated that the talking stick learning model triggers students to be ready at any time whenever they have a turn to speak. This helps students to have better performance.

In addition, (Asri, Nurhalim, \& Suhandini (2019) stated that this talking stick learning model trains students to always be ready, more skilled in reading, and quickly understand materials. (Hartanti \& Hardinto, 2017) explained that students' enthusiasm in the learning process was one of the evidence that their learning outcomes increased compared to cycle I. Each student must be ready to answer questions when the stick stopped at them. For this reason, they prepare to study hard. They are brave enough to speak because they are confident. Another advantage of the talking stick learning model is the equal opportunity for all students to express their thoughts, ideas, and opinions about an issue.

Based on the results of the Mann Whitney $\mathrm{U}$ test analysis, the Sig value of 0.000 is higher than 0.05 , meaning that Ho is rejected. The Mann Whitney U test result showed that the speaking skills between the experimental and control groups differed significantly. Furthermore, the average change in the speaking skills of the control group was 0.34 , which is lower than the experimental group with 1.7. The learning activities in the control group are the same as the previous activities, namely by presentations, lecturing, and followed by a question-and-answer sections as well as assignments. This conventional learning model is not optimum to improve students' speaking skills.

\section{Conclusion}

Based on data analysis and theoretical studies that have been explained above, and the result of the hypothesis test, it can be concluded that the talking stick learning model has a positive and significant impact on the speaking skills of the $4^{\text {th }}$ semester students of UST Yogyakarta. It is evidenced by the experimental group with the use of the talking stick learning model, which shows average post-test scores of 8 (excellent) and in control with the use conventional learning model with the average score of 6.84 (good). Referring to the result of this research, the researchers provide some suggestions. First, for lecturers they need to apply the talking stick learning model as an effort to improve students 'speaking skills. Second, for the university, it is important to consider the use of this model as innovative learning activities to improve students' speaking skills to maintain and increase the quality of education. The last, future researchers can conduct further research related to the talking stick model to improve speaking skills.

\section{References}

Abbas, S. (2006). Pembelajaran bahasa Indonesia yang efektif di sekolah dasar. Departemen Pendidikan Nasional.

Akhadiah, S., Sabarti, M. G. A., \& Sakura, H. R. (1991). Bahasa Indonesia 1. Depdikbud.

Ananda, E. (2017). Improving students speaking performance by using Talking Stick method (pp. 2-11).

Asri, B. W., Nurhalim, K., \& Suhandini, P. (2019). The implementation of talking stick model assisted by audio-visual media toward positive character and learning outcome. Journal of Primary Education, $8(15), 225-231$.

Douglas, D. A. N., \& Frazier, S. (2001). Teaching by principles: An interactive approach to language Pedagogy. Tesol Quarterly, 35(2), 341-342.

Hartanti, D. A., \& Hardinto, P. (2017). The application of Fusion Learning Model Talking Stick and Course Review Horey to increase activeness and learning outcomes. Classroom Action Research Journal (CARJO), 3(1), 117-124. https://doi.org/10.17977/um099v1i32017p117

Hasyim, A. (2018). The implementation of student team achievement division and talking stick on economics subject. Classroom Action Research Journal (CARJO), 2(3), 95-100. https://doi.org/10.17977/um013v1i42017p156

Huda, M. (2015). Model-model pengajaran dan pembelajaran. Pustaka Belajar.

Ishaq, I. (2008). Model-model pembelajaran mutakhir: Perpaduan Indonesia-Malaysia. Pustaka Belajar.

Istarani, I. (2012). 58 model pembeloajaran inovatif. Media Persada.

Jacobs, G. M., \& Kimura, H. (2013). Cooperative learning and teaching. Tesol Publications.

Jacobs, G. M., \& Renandya, W. A. (2019). Student centered cooperative learning: An introduction. In student centered cooperative learning. Springer. https://doi.org/10.1007/978-981-13-7213-1_1

Jolliffe, W. (2007). Cooperative learning in the classroom: Putting it into practice. SAGE Publications Ltd.

Kagan, S. K. M. (2009). Cooperative learning. Kagan Publishing.

McConnell, D. (2014). Implementing computing supported cooperative learning (1st ed.). Routledge. https://doi.org/https://doi.org/10.4324/9781315042275

Rofi’Uddin, A., \& Zuhdi, D. (1998). Pendidikan bahasa dan sastra Indonesia di kelas tinggi. Proyek pendidikan guru Sekolah Dasar (Primary School Teacher Development Project). Direktorat Jenderal Pendidikan Tinggi, Departemen Pendidikan dan Kebudayaan. 
Sari, A. S. P., \& Sembiring, R. K. B. (2019). Improving students' english-speaking skill through the implementation of Talking Stick method to the fifth-grade students at state primary school 028226 Binjai. Budapest International Research and Critics in Linguistics and Education (BirLE) Journal, 2(4), 507-513. https://doi.org/10.33258/birle.v2i4.552

Sari, D. M. (2017). Analysis of students' mathematical communication ability by using Cooperative Learning Talking Stick type. Infinity Journal, 6(2), 183. https://doi.org/10.22460/infinity.v6i2.p183-194

Sartipa, D. (2017). Talking stick in speaking ability. Edukasi Lingua Sastra, 17(2), 159-164.
Slavin, R. (2009). Cooperative learning: Teori, riset, dan praktik. Nusa Media.

Supridjono, A. (2009). Cooperative learning: Teori dan aplikasi Paikem. Pustaka Belajar.

Tarigan, H. G. (1991). Metodologi pengajaran bahasa. Proyek pengembangan lembaga pendidikan tenaga kependidikan, Direktorat Jenderal Pendidikan Tinggi, Departemen Pendidikan dan Kebudayaan. Angkasa.

Tarigan, H. G. (2015). Berbicara sebagai suatu keterampilan berbahasa. Angkasa. 